\title{
Determinants of Dividend Policy: A Panel Data Analysis for Turkish Listed Firms
}

\author{
Narman Kuzucu ${ }^{1}$ \\ ${ }^{1}$ School of Business and Management Sciences, Istanbul Medipol University, Turkey \\ Correspondence: Narman Kuzucu, School of Business and Management Sciences, Istanbul Medipol University, \\ Turkey. E-mail: narmankuzucu@gmail.com
}

Received: September 8, 2015

Accepted: October 19, 2015

Online Published: October 28, 2015

doi:10.5539/ijbm.v10n11p149

URL: http://dx.doi.org/10.5539/ijbm.v10n11p149

\begin{abstract}
Dividend policy of firms is one of the most controversial issues of theoretical finance. This paper aims to investigate the firm-level factors influencing the dividend decisions of firms from an emerging market. We examined eight-year panel data for the period from 2006 to 2013 from the Turkish stock market (Borsa Istanbul). The results show that financial leverage, size, growth rate, age, profitability, ownership structure and P/E ratio are statistically significant. The relationship of leverage, growth rate, profitability and family control with dividends is negative, whereas the relationship of size, age and $\mathrm{P} / \mathrm{E}$ ratio is positive. Therefore, firms with higher debt ratios / growth rates / higher earnings are likely to retain more of their earnings. The empirical evidence from the Turkish stock market shows that the maturity hypothesis proposed by Grullon, Michaely and Swaminathan (2002) best explains the dividend behaviors of firms. Accordingly, as a firm matures, the availability of profitable projects reduces and earnings decrease. As the investment opportunities reduce, the need for resources decreases and the firm increases dividend payouts to shareholders.
\end{abstract}

Keywords: dividend, payout policy, dividend policy, panel data analysis, Borsa Istanbul

\section{Introduction}

A dividend decision is one of the most important financial decisions of a firm. Firms try to determine the level of internal financial resources and, at the same time, are assumed to maximize their shareholders' wealth through dividend policy. In the theoretical context, dividends have been both a core topic and a controversial area of finance since the dividend irrelevance theory proposed by Miller and Modigliani (1961). Indeed, a great majority of financial aspects, including capital structure theories, mergers and acquisitions, asset pricing and capital budgeting, are closely related to the views regarding how and why firms pay out dividends. The determinants of firms' dividend policies help us to understand the so-called dividend puzzle to some extent.

Many researchers have examined dividends and investigated which factors influence the dividends and dividend payout decisions of firms. The theoretical models of dividends are based on the effects of informational content, agency costs, taxes, transaction costs, clientele effects and the demands/preferences of shareholders. The determinants of dividends generally refer to the firm-specific factors influencing the dividend payout ratios. Prior studies show that profitability, size, industry, ownership structure, capital structure and maturity of the firm, as well as other firm-level factors, are related to dividend payouts.

In this study, we try to identify and test the firm-level factors influencing the dividend payouts. We examine the relationships of various firm characteristics with dividends by using the data from the Turkish stock market: Borsa Istanbul (BIST). Panel data of an eight-year period from 2006 to 2013 is used. The study aims to contribute to the empirical literature on dividend policy by providing panel data results and evidence from an emerging market (Note 1).

The remainder of the paper proceeds as follows: Section 2 presents a brief literature review on the determinants of dividends and, additionally, the literature on the dividend policy of Turkish listed firms. Section 3 describes the hypotheses and the methodology of the study. The results of the research are discussed in Section 4. Finally, the findings of the study are summarized in the conclusion. 


\section{Literature Review}

\subsection{Prior Empirical Researches on Determinants of Dividends}

Earnings have been the main determinant on which most researchers have focused, beginning from the pioneering study by Lintner (1956). Lintner proposes that a firm is assumed to have a desired level of dividends that is based on its expected earnings. In his model, the changes in earnings and the expectations regarding the level of earnings determine a firm's dividend policy. Fama and Babiak (1968), Pruitt and Gitman (1991) and Baker and Powell (1999) support Lintner's findings. Skinner and Soltes (2011) examined the relationship between the dividends and earnings quality. Dividends provide information on the sustainability of the firm's earnings. They find that the relation between current earnings and future earnings is stronger for dividend-payer firms in comparison to non-payers.

Firm size and profitability are the two determinants most commonly researched in relation to dividends. Jensen and Meckling (1976) and Jensen, Donald and Zorn (1992) find that large and profitable companies were more likely to increase their dividend payouts. Smith and Watts (1992) find that dividend yield is positively related to firm size by using industry-level data.

One of the most highly cited researches on the determinants of dividends was done by Fama and French (2001). They examined the characteristics of dividend-payer firms. They found that larger and more profitable firms have a higher propensity to pay out. Accordingly, dividends have a positive relationship with size and earnings.

DeAngelo, DeAngelo, and Skinner (2004) extended the study by Fama and French (2001). Their main focus was on the concentration in dividends. Their results are consistent with Fama and French. Larger scale and higher earnings in firms are associated with higher dividends. Denis and Osobov's (2008) research is consistent with that by DeAngelo et al. Skinner and Soltes (2011) report that payout ratios are positively related to size. On the other hand, Grullon, Michaely, and Swaminathan (2002) find an inverse relationship between dividends and profitability (firm performance). Return on assets represents profitability, not earnings level, in their research.

Growth and investment opportunities influence the dividend decisions of firms. High-growth firms are more likely to retain internally generated funds and use those to finance their investments (Rozeff, 1982a; Myers \& Majluf, 1984; Jensen et al., 1992). Therefore, there is a negative relationship between dividends and growth opportunities. Smith and Watts (1992) find that dividend yield is negatively associated with growth options of firms. Gaver and Gaver (1993) report that high-growth firms have lower payout ratios and lower dividend yields. Fama and French (2001) have supportive findings in their study. They found that dividends have a negative relationship with growth ratio, whereas dividends have a positive relationship with size and earnings.

Michel (1979) presents evidence that a firm's industry influences its dividend policy. He reported that industry classification was strongly related to dividend payouts. Rozeff (1982b) proposed that the industry of a firm did not explain its dividend payout ratio, intentionally excluding the utilities firms from his analysis because of their regulatory status.

Baker, Farrelly, and Edelman (1985) examined the industry effect on dividend policy of firms in three main industry groups: utility, manufacturing and wholesale/retail. They reported that utilities have high payout ratios and the dividend decisions of utilities firms differ. They attribute this to the regulated nature of the utilities industry. The utilities firms view the world differently due to the monopoly power and the non-competitive environment in the industry. The findings of Baker and Powell (1999) are consistent with Baker et al. (1985).

A different approach called "catering incentives" was proposed by Baker and Wurgler (2004). The main proxy used by them is the price-to-book ratio. Firms increase dividends when investors put a relatively high stock price on dividend-payer firms, and vice versa. Accordingly, dividends are associated with higher price-to-book values.

Firms with high financial leverage are expected to have low dividend payout ratios. Highly leveraged firms pay lower dividends to reduce their transaction costs (Rozeff, 1982a; Jensen et al., 1992). There is a negative correlation between leverage and dividends because highly leveraged firms decrease their dividends due to the costs of external financing (Rozeff, 1982a). However, Jensen (1986) proposed that debt may be a substitute for dividends by reducing free cash flow and, therefore, agency costs. Smith and Watts (1992) and Gaver and Gaver (1993) find a positive relationship between dividend yield and leverage in their studies based on growth and non-growth firms' data. They report that growth firms have significantly lower leverage ratios and lower dividend yields.

DeAngelo and Stulz (2006) examined the effect of capital structure by using the ratio of retained earnings to total equity or to total assets of a firm as a proxy for a firm's lifecycle stage. They find that a mix of earned and contributed capital has more impact than profitability, growth, firm size, leverage and cash balances on dividend 
payouts.

Ownership structure affects dividend policy, especially due to large controlling shareholders. Because large controlling shareholders, such as a family, have large voting rights, they may adopt a dividend policy in which the firm distributes no or low dividends (Shleifer \& Vishny, 1986). Sometimes a large (controlling) shareholder is an institutional investor, not a family or individual. An institutional investor may prefer a dividend policy with high dividends. Tax-exempt shareholders, such as pension funds, prefer receiving dividends. There is extensive literature examining the dividend preferences of institutional investors under clientele effects (Miller \& Scholes, 1978; Michaely, Thaler, \& Womack, 1995; Grinstein \& Michaely, 2005).

Another determinant of dividends is a firm's risk level. In the literature, the relationship between dividends and firm risk is negative. Rozeff (1982a) found a negative relationship between dividends and firm risk. Grullon et al. (2002) investigated the relation between dividend changes and change in systematic risk. They find that dividend-increasing (decreasing) firms experience a significant decrease (increase) in their systematic risk. The rationale behind their research is that investment opportunities become smaller when the firms become more mature.

\subsection{Prior Studies on Dividends of Turkish Listed Firms}

In contrast to the extensive literature regarding dividend policies of established markets such as the USA, the UK, Canada and others, there are a relatively limited number of studies on dividends of emerging-market stocks. BIST of Turkey is one of the emerging markets and, with its total market capitalization value at more than USD 200 billion, and where global investors hold more than $60 \%$ of total shares registered, it deserves to be studied.

Adaoglu (2000) investigated the dividend policy behaviors of BIST companies and examined whether they follow a stable dividend policy in the same way as developed markets' companies. He concluded that the companies traded at BIST had unstable dividend policies, unlike those in developed European and American markets. He used Lintner's dividend model to test the stability and regulation effect. His results showed that BIST companies had unstable dividend policies between 1985 and 1997. The instability rose significantly after the regulation change in 1995 . He found that the main determinant of dividends was earnings. The instability in the earnings of BIST caused the instability in the dividends.

Yurtoglu (2000) examined the ownership structure of Turkish listed companies. He reported that concentrated ownership has a negative relationship with the return on assets, price-to-book ratios and dividend payouts. Thus, he proposed that concentration on the ownership of companies affected the performance of listed companies negatively. He used the dividend payout ratio as a proxy for firm performance, as well as return on assets and price-to-book ratio, because he considered that the return on investments of minority shareholders is determined by the payout ratio.

Yilmaz (2003) examined the dividend policy of BIST firms, focusing on industrial differentiation between 1986 and 2001. He showed that firms were more likely not to pay out dividends after mandatory dividend payouts were abandoned in 1995. He used the conception of net cash dividends, which refers to "cash dividends - rights offerings," in the analysis. He emphasized that the average payout ratio of the financial sector experienced a sharp decrease and became the lowest dividend payer among the other industries after the abolishment of mandatory dividends in 1995.

Aivazian, Booth, and Cleary (2003) examined the determinants of dividend policies in eight emerging markets, including Turkey. They compared the dividend behaviors of emerging-market companies with the ones in the USA. They found that profitability, size, leverage and price-to-book ratio are the main determinants of dividends. They proposed that the companies in emerging markets followed unstable dividend policies.

Adaoglu (2008) examined the dividend behaviors of BIST firms from 1986 to 2007. He investigated the disappearance and concentration of dividends in Turkey. He found that the number of payers decreased while the dividends level increased. His findings are consistent with the evidence in the USA market exhibited by DeAngelo et al. (2004). He also examined the size effect on dividends and found that the payout ratio gets larger while the size of the industrial companies gets bigger.

Altiok-Yilmaz and Akben (2010) investigated the market reaction to dividend-change announcements of BIST companies. They used event study methodology with the data covering the period from 2005 to 2008. They concluded that the market reacts to dividend announcements. Their results showed that market reactions are positive (negative) in case of dividend increases (decreases), whereas there is no reaction when dividends are unchanged. The resulting evidence is consistent with a signaling hypothesis.

Kirkulak and Kurt (2010) examined the dividend policy of BIST firms from 1991 to 2006. They report the 
decreasing number of payers and the declining amount of real dividends in the period. They also show that earnings and dividends concentration decreased in the sampled period. They investigated the determinants of dividend payouts of BIST firms. They concluded that earnings and high growth potential are the main determinants of a dividend decision, and there is a positive correlation between dividends and earnings and high growth potential.

Kuzucu (2015) conducted a survey to examine the perceptions of financial managers on corporate dividend policy of Turkish listed, non-financial firms. His results suggest that earnings are the most important factor which influences the payout decision. Desire to distribute a proportion of earnings to shareholders, sustainable change in earnings, financial leverage, and stability and level of future earnings are the most common determinants of dividend policy. Furthermore, he investigated share repurchase decisions of Turkish firms based on the financial managers' opinions. Accordingly, the most likely determinant of share repurchase decisions is undervaluation of stock price.

\section{Research Data and Methodology}

A panel data analysis (longitudinal research) is done to examine the factors influencing the dividend payouts using the data of non-financial BIST firms for the period of eight years from 2006 to 2013 in this study. A fixed-effects (FE) model and a pooled OLS regression model are employed to test the effects of firm-level factors on dividend decisions of firms. The main feature of this study, distinguishing it from prior studies on Turkish listed firms, is that it investigates many factors influencing dividends together. It includes a number of relevant determinants such as size, earnings, liquidity, growth, capital structure, industry, ownership and so on in the analysis simultaneously.

\subsection{Hypotheses and Description of Variables}

Many firm-specific factors influence the corporate dividend policy, as well as outside effects such as regulations and general economic conditions. In this study, we investigate which firm-specific factors influence the payout policy. The external factors are beyond the scope of this study. Thus, the market-specific, external effects are ignored. The list of dependent and independent variables are given in Table 1 . The dependent variable is the payout ratio as the proxy for the dividend decision. Firms decide to increase, decrease or not change dividends in their corporate dividend policies. The payout ratio measures the magnitude of dividends relative to earnings. Thus, the most appropriate proxy for dividend policy is the payout ratio.

Table 1. Definitions of variables

\begin{tabular}{|c|c|c|c|c|}
\hline Factors & Variables & Description & Name & $\begin{array}{l}\text { Hypoth. } \\
\text { Sign }\end{array}$ \\
\hline Dividend Decision & Dividend Payout Ratio & Dividends Paid out / Net Earnings & DPR & DV \\
\hline Liquidity & Current Ratio & Current Assets / Current Liabilities & $\mathrm{CR}$ & + \\
\hline Leverage & Debt to Total Assets & Total Liabilities / Total Assets & DA & - \\
\hline Growth Opportunities & Asset Growth Rate & 5 Year Compound Annual Growth rate in Total Assets & GROW & - \\
\hline $\begin{array}{l}\text { Growth Opportunities } \\
\text { (tentative) }\end{array}$ & Price / Earnings & Price of the Stock / EPS & $\mathrm{PE}$ &,+- \\
\hline Size & Total Assets & The natural $\log$ of total assets & SIZE & + \\
\hline Earnings & Earnings per Share & $\begin{array}{l}\text { Net Earnings / the Number of Shares Outstanding } \\
\text { (adjusted to that each share has a nominal value of one } \\
\text { Turkish Lira) }\end{array}$ & EPS & + \\
\hline Market Valuation & Price-to-Book Ratio & Market Capitalization / Book Value & PB & + \\
\hline Industry & Industry & $\begin{array}{l}\text { Manufacturing }=1 \text {, } \\
\text { Non-manufacturing }=0\end{array}$ & IND & + \\
\hline Ownership & Family Control & Family-controlled $=1$, Otherwise $; 0$ & OWN & - \\
\hline Maturity & Age of the Firm & Current Year - Establishment Year of the Firm & AGE & + \\
\hline Outsider Ownership's Influence & Floating Rate & $\begin{array}{l}\text { The number of freely traded shares /Total number of } \\
\text { shares outstanding }\end{array}$ & FLO & + \\
\hline
\end{tabular}

Stock dividends are beyond the scope of this study. Therefore, a firm's liquidity is expected to affect its dividends because dividends must be paid out in cash. The current ratio is used to measure liquidity. The liquidity ratio, which indicates the cash and cash equivalents relative to total assets, is not preferred because a dividend decision is not made in a very short time period. Thus, the current ratio, which is measured by the total current assets, is used as a proxy. Firms with greater liquidity are expected to pay out more dividends. Therefore, it is hypothesized that there is a positive relationship between liquidity and payout ratio. 
Dividend payouts decrease the ratio of equity relative to debts on the balance sheet. On the other hand, firms need financial resources to place in investments. A firm which needs funding either retains more earnings or issues debt. A firm which has greater propensity to retain earnings is expected to have less financial leverage. In other words, firms with higher payout ratios are assumed to use less financial leverage. Debt increases transaction costs. Highly leveraged firms pay lower dividends to reduce their transaction costs (Rozeff, 1982a; Jensen et al., 1992). Thus, we hypothesize that financial leverage has a negative relation with dividends.

High-growth firms need more funds to finance their growth. They use both internal and external financial resources. High-growth firms tend to retain earnings (Fama \& French, 2001). Therefore, we hypothesize that the firms with higher growth rates are likely to pay out lower dividends. A five-year annual average asset growth rate is used for a proxy for growth opportunities, as suggested by Kallapur and Trombley (1999). They examined the performance of various growth and investment opportunity proxies. They proposed that the growth rate of total assets best measures the growth opportunities of a firm. The hypothesized relationship between growth opportunities and dividends is negative.

Most analysts accept that the price-to-earnings (PE) ratio represents the growth opportunities of a firm. In their research, Brav et al. (2005) used the PE ratio as a proxy for growth opportunities. The PE ratio is an increasing function of the payout ratio and the growth rate and a decreasing function of riskiness. It increases as the payout ratio increases (Damodaran, 2002). Indeed, the forward PE ratio, which is a function of estimated net earnings in the future, indicates growth opportunities more accurately than actual earnings. Nevertheless, the estimated earnings for listed firms are not always available. Even if the estimates by analysts were available, their accuracy and fairness would perhaps be questionable. Thus, current PE ratios were used as a proxy for growth opportunities, as well as asset growth rate, but with some caution. The hypothesized sign is tentative.

Large firms generally have easy access to capital markets and are likely to retain fewer earnings to finance investments. Many researchers investigated whether size matters in the context of dividends. Large companies are more likely to increase their dividend payouts to decrease agency costs. The prior findings show that larger firms are more likely to pay more (Jensen et al., 1992; Fama \& French, 2001; Aivazian et al., 2003; Adaoglu, 2008). A positive relationship between dividends and firm size is hypothesized.

Earnings are one of the most important determinants of a dividend decision. In the ordinary course of things, only firms with positive earnings are expected to pay out. A firm's profitability is expected to be positively related to dividend payouts, as the majority of the dividend literature reports (Jensen et al., 1992; Fama \& French, 2001; Aivazian et al., 2003; Kirkulak \& Kurt, 2010). We hypothesize that there is a positive relationship between earnings and dividend payments.

The price-to-book $(\mathrm{PB})$ ratio indicates the market valuation of the firm relative to its book value. Aivazian et al. (2003) use it to measure the importance of investment opportunities and as a proxy for the present value of growth options, and they find a positive relationship with dividends. We hypothesize that the larger the PB ratio of a firm, the more likely it is to pay out.

Financial firms such as banks, insurance companies, holding companies and investment trusts are excluded from the analysis. Thus, manufacturing, wholesale and retail traders, and services companies are in the context of the industry examination. Industry effect is tested as to whether being within the manufacturing industry or not is related to dividend payouts. A dummy variable is used to test industry effect. Manufacturing firms are hypothesized to pay out more as their earnings levels and profitability ratios are assumed to be higher than those of non-manufacturing firms. However, Rozeff $(1982 \mathrm{~b})$ proposed that the industry of a firm is irrelevant to its dividend payout ratio.

Family-controlled firms are generally managed by insider owners. Agency costs are likely to be lower in the family- and individual-controlled firms. Those kinds of firms are not expected to pay out large amounts of dividends due to concentration in ownership (Shleifer \& Vishny, 1986; La Porta et al., 2000). A dummy variable is included to test the effect of the ownership factor. We hypothesize that there is a negative relationship between family control and the dividend payout ratio.

Mature companies pay out more and have greater payout ratios than growth firms (Grullon et al., 2002). Firms which reach the maturity stage initiate or increase dividends. They are likely to retain earnings in their earlier stages. The firm lifecycle theory and maturity hypothesis are based on that notion. DeAngelo et al. (2006) propose that the earned capital / contributed capital mix is lower during the earlier stages of a firm, and then the ratio of retained earnings (earned capital) to its equity (or total assets) rises in the further stages. Thus, they use the ratio of retained earnings to total equity (RE/TE) as a proxy in their lifecycle theory. Nevertheless, we prefer not to use the ratio of RE/TE in the study because Turkish listed firms often add retained earnings into the 
paid-in capital and distribute stock dividends to their stockholders. This fact avoids tracking the share of earned capital in the total equity. Thus, the maturity of a firm is represented by the age of the firm in the analysis. We hypothesize that there is a positive relationship between the age of a firm and its dividend payout ratio.

La Porta et al. (2000) propose that minority shareholders extract high dividends from firms and they want to use their legal power (i.e. voting) to be provided with dividends under agency problems. Thus, insiders are likely to raise dividends to attract minority shareholders. The floating rate is used as a proxy for outsider ownership's influence. We hypothesize that the higher the outsider ownership, the higher the dividend payout ratio.

\subsection{Sample Set}

The financial and non-financial data are obtained from the archive on the website of Borsa Istanbul (BIST) and the annual reports of firms. Financial ratios were calculated by using the financial information of firms' audited financial statements. Dividend payouts during the eight-year period between 2007 and 2014 on BIST are examined. That means the earnings and the financial reports of the fiscal years between 2006 and 2013 are used in the research. Financial-sector firms, including banks, insurance companies, holdings and investment trusts, are excluded from the data set as they have different financial structures and bookkeeping practices according to the different nature of their business. A few payouts with negative earnings in which the dividends were distributed from free equity reserves are excluded from the data set. Thus, a data set which covers 626 firm-year observations from 142 firms is obtained. The summary statistics of the sample set are presented in Table 2 .

Table 2. Summary statistics

\begin{tabular}{llllll}
\hline Variable & N & Mean & St. Dev. & Min & Max \\
$D P R$ & 626 & 0.551 & 0.287 & 0.031 & 1.000 \\
$C R$ & 626 & 2.126 & 3.609 & 0.120 & 64.592 \\
$D A$ & 626 & 0.379 & 0.203 & 0.018 & 0.961 \\
GROW & 626 & 0.185 & 0.189 & -0.376 & 1.439 \\
SIZE (Log) & 626 & 20.075 & 1.513 & 16.014 & 23.774 \\
$E P S$ & 626 & 2.290 & 11.209 & 0.001 & 176.65 \\
$P E$ & 626 & 16.397 & 19.490 & 0.879 & 231.8 \\
$P B$ & 626 & 2.146 & 2.269 & 0.284 & 16.639 \\
$A G E$ & 626 & 37.093 & 14.141 & 4 & 70 \\
$F L O$ & 626 & 0.261 & 0.147 & 0 & 0.670 \\
$I N D$ (Dummy) & 626 & 0.778 & 0.416 & 0 & 1 \\
OWN (Dummy) & 626 & 0.498 & 0.500 & 0 & 1 \\
\hline
\end{tabular}

\subsection{Methodology}

Panel data (also known as cross-sectional time-series data) is a dataset in which the behavior of entities, firms or countries are observed across time. Not all dividend-payer firms have valid data for each of the selected years due to dividend omissions in the sample set. Thus, the dataset for dividend payouts is unbalanced. A fixed-effects model is generally used when analyzing the impact of variables that vary over time. FE panel data analysis examines the relationship between explanatory variables and the explained variable. FE models remove the effect of time-invariant characteristics (Wooldridge, 2010). Thus, the net effect of the predictors on the explained variable can be assessed. The impact of time-invariant firm characteristic variables, such as industry and ownership structure, on a firm's dividend payout ratio is investigated by using a pooled OLS model. The payout ratio is the dependent variable and used as a proxy for the dividend decision in the model. Therefore, the relationship is represented by the below equation:

\section{Dividend Decision $=f$ (Liquidity, Leverage, Growth, Size, Profitability, Price/Earnings, Market Valuation, Industry, Family Control, Maturity, Outsider Ownership)

Two panel data models and a pooled OLS model are formed to estimate the dividend decision within the equation above. In the three models, the dependent variable is the same: the dividend payout ratio. Panel data regression models are incorporated in the below equation:

$$
D P R_{i t}=\beta_{0}+\beta_{1} X_{1, i t}+\ldots . .+\beta_{k} X_{k, i t}+\epsilon_{i t}
$$

where $D P R$ is the dividend payout ratio of firm $i$ in year $t$; $X_{k, i t}$ represents independent firm-specific variables; $\beta_{k}$ is the coefficient for the independent variables; $\epsilon_{i t}$ is the error terms. 
Model 1 examines the impact of size, whereas Model 2 investigates the impact of age as a proxy of maturity. We try to estimate the effect of firm-specific factors - liquidity, leverage, growth opportunities, size, earnings level, price/earnings ratio, market valuation, maturity of the entity, and outsider ownership-on the dividend payout ratio. The definitions of variables used as proxies are presented in Table 1.

In order to determine whether the panel data is fixed effects or random effects, a Hausman (1978) specification test is performed. Accordingly, the two panel data analyses are found to be the FE model. The effects of time-invariant factors-industry and family control - on payout ratio are investigated by the help of a pooled OLS regression model. Two dummy variables are utilized in the linear regression model; industry (IND) and ownership (OWN) variables. The floating rate (FLO) is roughly a time-invariant variable across years, and it is considered constant for each firm. An industry dummy variable is included to investigate whether being a manufacturing or non-manufacturing firm explains dividends. An ownership variable is included to estimate the effect of family control on dividend decisions. A stepwise linear regression method is run, considering that stepwise regression searches for best models by trying and omitting each independent variable. Yet, the general results of the research are based on the FE panel data analysis.

\section{Results and Discussions}

\subsection{Correlation Coefficients and Multicollinearity}

Multicollinearity occurs when the model includes multiple factors that are correlated not just to a dependent variable, but also to each other. Table 3 exhibits Pearson correlation coefficients of the variables for the period between 2006 and 2013. The table shows that the correlation between the independent variables used in the model is generally quiet small. The largest correlation coefficients exist between the size and leverage variables (39.9\%), between PE and PB ratios (39.5\%), and between current ratio and leverage variables (-33.9\%). In a case of multicollinearity, high correlation between two or more independent variables exists, and the beta coefficients cannot be estimated with appropriate precision or accuracy. The existence of high R-squared values is a symptom of multicollinearity. Additionally, in a case of high pair-wise coefficient correlations among explanatory variables, multicollinearity is suspected. There are not high coefficient correlations between the independent variables. Furthermore, the R-squared value is not high. Therefore, we do not suspect the existence of a multicollinearity problem.

Table 3. Pearson correlation coefficients of the variables for the selected period

\begin{tabular}{|c|c|c|c|c|c|c|c|c|c|c|}
\hline & DPR & CR & DA & SIZE & GROW & EPS & PE & PB & AGE & FLO \\
\hline DPR & 1 & & & & & & & & & \\
\hline CR & $0.078 * *$ & 1 & & & & & & & & \\
\hline DA & $-0.127 * * *$ & $-0.339 * * *$ & 1 & & & & & & & \\
\hline SIZE & $-0.073^{*}$ & $-0.234 * * *$ & $0.399 * * *$ & 1 & & & & & & \\
\hline GROW & $-0.197 * * *$ & 0.040 & $0.155^{* * *}$ & -0.025 & 1 & & & & & \\
\hline EPS & $-0.116^{* * *}$ & -0.024 & $-0.078^{*}$ & $-0.101 * *$ & 0.064 & 1 & & & & \\
\hline PE & $0.140 * * *$ & $0.069^{*}$ & -0.004 & $-0.111 * * *$ & -0.005 & -0.025 & 1 & & & \\
\hline PB & $0.109 * * *$ & 0.033 & $0.124 * * *$ & 0.009 & $0.112 * * *$ & $0.072 *$ & $0.395 * * *$ & 1 & & \\
\hline AGE & 0.001 & -0.051 & $-0.123 * * *$ & $0.223 * * *$ & $-0.216^{* * *}$ & -0.007 & $-0.120 * * *$ & $-0.241 * * *$ & 1 & \\
\hline FLO & -0.048 & 0.022 & $0.137 * *$ & -0.047 & $0.089 * *$ & 0.038 & -0.062 & 0.019 & $-0.117 * * *$ & 1 \\
\hline
\end{tabular}

Note 1. $* * * * *$ and $*$ denotes significance levels of $1 \%, 5 \%$, and $10 \%$, respectively.

Note 2. The definitions and abbreviations of the variables were already given in Table 1.

\subsection{The Tests for Heteroskedasticity and Autocorrelation}

The panel data regression results were tested to determine some econometric problems such as heteroskedasticity and autocorrelation. A modified Wald test was used to determine the heteroskedasticity in the fixed-effects models in the study and a Breusch-Pagan test was used to detect the heteroskedasticity in the pooled OLS model. A Wooldridge test was run to check the presence of autocorrelation in the panel data. Panel data FE models in the study encounter both heteroskedasticity and autocorrelation, whereas the pooled OLS model is homoscedastic, but autocorrelated. If the models encounter a heteroskedasticity problem, then the "usual" OLS standard errors are invalid, and some corrective action should be taken. In the presence of both heteroskedasticity and autocorrelation in the panel data fixed-effects model, the standard errors are corrected 
by heteroskedasticity and autocorrelation consistent standard errors such as the Arellano-Froot-Rogers estimator, and the results should be interpreted afterwards. Likewise, in a pooled OLS model, when autocorrelation and/or heteroskedasticity are present, robust standard errors should be used. Robust standard errors may be obtained by Huber, Eicker and White estimators (Wooldridge, 2010).

\subsection{Discussions and Evaluations of Results}

After correcting the regression models by using the mentioned robust estimators, we obtain the results presented in Table 4. According to the regression results, leverage, growth rate, size, earnings per share, PE ratio and ownership structure are found to be statistically significant explanatory variables at different levels of significance. The current ratio (a proxy for liquidity), price-to-book value, floating rate (a proxy for outsider ownership influence) and the industry dummy variable are not statistically significant variables in the study. The insignificance of the price-to-book value does not submit evidence for the catering theory, which simply calls the dividend premium as the difference between the average price-to-book ratio of dividend payers and non-payers.

Table 4. Results of the panel data regression models with robust estimators

\begin{tabular}{|c|c|c|c|}
\hline & $\begin{array}{l}\text { Panel Data FE } \\
\text { Model } 1\end{array}$ & $\begin{array}{l}\text { Panel Data FE } \\
\text { Model } 2\end{array}$ & $\begin{array}{l}\text { Stepwise Pooled } \\
\text { OLS Regression }\end{array}$ \\
\hline Variables & DPR & DPR & DPR \\
\hline $\mathrm{CR}$ & $\begin{array}{l}0.002 \\
(0.005)\end{array}$ & $\begin{array}{l}0.002 \\
(0.005)\end{array}$ & \\
\hline $\mathrm{DA}$ & $\begin{array}{l}-0.490^{* * *} \\
(0.162)\end{array}$ & $\begin{array}{l}-0.487 * * * \\
(0.160)\end{array}$ & $\begin{array}{l}-0.174 * * * \\
(0.055)\end{array}$ \\
\hline GROW & $\begin{array}{l}-0.097^{*} \\
(0.057)\end{array}$ & $\begin{array}{l}-0.021 \\
(0.057)\end{array}$ & $\begin{array}{l}-0.269^{* * *} \\
(0.069)\end{array}$ \\
\hline SIZE & $\begin{array}{l}0.107 * * * \\
(0.036)\end{array}$ & & \\
\hline EPS & $\begin{array}{l}-0.004 * * * \\
(0.001)\end{array}$ & $\begin{array}{l}-0.005 * * * \\
(0.001)\end{array}$ & $\begin{array}{l}-0.003 * * * \\
(0.000)\end{array}$ \\
\hline $\mathrm{PE}$ & $\begin{array}{l}0.004 * * * \\
(0.001)\end{array}$ & $\begin{array}{l}0.004 * * * \\
(0.001)\end{array}$ & $\begin{array}{l}0.001 * * \\
(0.001)\end{array}$ \\
\hline PB & $\begin{array}{l}0.001 \\
(0.012)\end{array}$ & $\begin{array}{l}-0.002 \\
(0.012)\end{array}$ & $\begin{array}{l}0.015^{* * * *} \\
(.004)\end{array}$ \\
\hline AGE & & $\begin{array}{l}0.017 * * * \\
(0.005)\end{array}$ & \\
\hline FLO & & & \\
\hline IND & & & \\
\hline OWN & & & $\begin{array}{l}-0.040^{*} \\
(0.022)\end{array}$ \\
\hline Constant & & & $\begin{array}{l}0.640 * * * \\
(0.028)\end{array}$ \\
\hline N. of observations & 626 & 626 & 626 \\
\hline Number of groups & 142 & 142 & \\
\hline $\mathrm{F}$ test & $12.26 * * *$ & $12.76 * * *$ & $23.80 * * *$ \\
\hline R-squared & 0.153 & 0.158 & 0.096 \\
\hline
\end{tabular}

Note 1. Standard errors in parentheses.

Note 2. Significant levels; *** $\mathrm{p}<0.01,{ }^{* *} \mathrm{p}<0.05,{ }^{*} \mathrm{p}<0.1$.

The most striking result is that the effect of earnings on dividends is found to be negative, which is in contrast to the hypothesis and to the majority of prior studies. The earnings are found to be significant but negatively related to the dividend payout ratio in our data set. The main reason is that only dividend payers' firm-year data are included in the data set. The omission years cannot be included in the panel data since the payout ratios in the respective years are not applicable in the panel data analysis. The data set covers 626 firm-year observations from 142 firms over eight years. This means a firm pays out, on average, 4.4 (626/142) times over eight years. Dividend omissions are apparently more frequent in Turkish firms compared to the firms in other markets. 
However, under this condition, the negative effect of earnings on dividends may still be interpreted as a firm with higher (lower) earnings tending to decrease (increase) its payout ratio (the magnitude of dividends relative to earnings). This result contradicts those found by Adaoglu (2000), Aivazian et al. (2003) and Kirkulak and Kurt (2010), who obtained evidence from BIST-listed firms, whereas it supports Grullon et al. (2002), who proposed the maturity hypothesis.

The signs of leverage and growth ratio variables are negative, as hypothesized, whereas the sign of profitability is negative, contradicting the hypothesis. That means firms with higher leverage ratios / growth rates / earnings levels are more likely to retain their earnings. In other words, highly-leveraged / high-growth / more profitable firms are associated with lower dividend payout ratios. The leverage ratio variable is significant at the $1 \%$ level, and it is the variable whose beta coefficient $(-0.49)$ is the largest in absolute value among the variables. These results, other than the negative sign of profitability, are consistent with Rozeff (1982a) and Jensen et al. (1992), and inconsistent with Smith and Watts (1992) and Gaver and Gaver (1993).

The growth ratio is found to be significant at the $10 \%$ level, with a negative sign. That means high-growth firms are likely to pay out fewer dividends and reinvest their internally generated cash flows. Size is found to be statistically significant at the $1 \%$ level, with a beta coefficient of 0.107 . Therefore, larger firms are associated with larger dividend payout ratios. In other words, the larger the firm, the larger the payout ratio. These results are consistent with prior literature (Fama \& French, 2001; DeAngelo et al., 2004; DeAngelo et al., 2006; Denis \& Osobov, 2008; Kirkulak \& Kurt, 2010).

The PE ratio is significant at the $1 \%$ level, and the sign of the variable is plus, whereas the hypothesis was tentative. The PE ratio was tentatively used as an alternative proxy for growth opportunities in the model, as suggested by Brav et al. (2004). The price-to-earnings ratio related to the expected earnings of a firm may represent the growth opportunities as suggested. Nevertheless, the realized historical values of earnings were used to calculate PE ratios. Therefore, the current PE ratio used in the model is not a good proxy for growth opportunities. Still, the PE ratio is significant in the model. The positive relationship with the payout ratio can be interpreted as evidence for the relevance of dividends to firm value to some extent. The positive relation of the $\mathrm{PE}$ ratio with the dividend payout ratio provides evidence that higher dividends are associated with higher stock prices.

The age of a firm is used as a proxy for the maturity of a firm. We aim to investigate the validity of the maturity hypothesis (Grullon et al., 2002). Age is found to be statistically significant at the $1 \%$ level. In the meantime, earnings are found to be negatively associated to the dividends in the study. As a firm matures, the availability of positive NPV projects reduces and earnings decrease. As the investment opportunities reduce, the need for resources decrease and the firm increases dividend payouts to shareholders. That is the best explanation for the results of the study. Therefore, supporting evidence for the maturity hypothesis was found in the study.

The family-control factor (dummy variable) relates with dividends at a $10 \%$ significance level, negatively as expected. Family- or individual-controlled firms are less likely to payout dividends, as hypothesized. This result is consistent with the common financial literature.

The dividend payout observations at any rates are included in the unbalanced panel data analysis. The regression analysis does not cover the non-payers' actions. For example, dividend omission of a firm in a year in the selected period may not be included in the sampling due to the inability of measuring no dividends, whereas an increase or decrease in dividend payout ratios is analyzed in the model. Therefore, the panel data results should be considered under this limitation.

\section{Conclusion}

The dividend behaviors of Turkish listed firms are examined in this study in order to investigate the firm-level determinants of dividends. Excluding financial-sector firms' data, the data of 626 firm-year payouts made by 142 firms during the period from 2007 to 2014 are included in the dataset to conduct panel data analysis. The panel data analysis results show that financial leverage, size, growth rate, age, profitability and PE ratio are statistically significant. The relationship of leverage, growth rate and profitability with dividends is negative, whereas size, age and PE ratio are positively related to dividend payouts. Therefore, firms with higher debt ratios / growth rates / earnings are likely to retain more of their earnings.

Family control is negatively related to dividend payout ratios. In other words, family- or individual-controlled firms are likely to retain more of their earnings. The result is as hypothesized and consistent with prior studies. The results of the panel data analysis of BIST-listed firms show that liquidity, price-to-book value, industry (manufacturing or non-manufacturing) and floating rate, which is a proxy for outsider ownership influence, are 
not statistically significant in explaining dividend payout ratios. The insignificance of the price-to-book value is inconsistent with the catering theory, which simply calls the dividend premium as the difference between the average price-to-book ratio of dividend payers and non-payers.

A striking result of the study is that the effect of profitability on dividends is found to be negative, which is in contrast to the majority of prior studies. On the other hand, size, age and PE ratio are positively related to dividend payout ratios and consistent with the prior literature. Accordingly, larger and more mature firms tend to pay out more dividends. These results support the maturity hypothesis, which is proposed by Grullon et al. (2002). As a firm matures, the availability of profitable investments reduces and earnings decrease. As the investment opportunities reduce, the need for resources decreases and the firm increases dividend payouts to shareholders. That is the best explanation for the results of the study.

\section{Acknowledgements}

I submit my thanks to Assoc. Prof. Dr. Emin Avci from Marmara University of Istanbul for his guidance during this study.

\section{References}

Adaoglu, C. (2000). Instability in the dividend policy of the Istanbul Stock Exchange (ISE) corporations: Evidence from an emerging market. Emerging Markets Review, 1, 252-270. http://dx.doi.org/10.1016/S1566-0141(00)00011-X

Adaoglu, C. (2008). Dividend policy of the ISE industrial corporations: The evidence revisited (1986-2007). Journal of BRSA Banking and Financial Markets, 2-2, 113-135. Retrieved March 1, 2014, from https://www.bddk.org.tr/WebSitesi/english/Reports/BRSA_Journal/6083makale\%205.pdf

Aivazian, V., Booth, L., \& Cleary, S. (2003). Dividend policy and organization of capital markets. Journal of Multinational Financial Management, 13, 101-121. http://dx.doi.org/10.1016/S1042-444X(02)00038-5

Altiok-Yilmaz, A., \& Akben, E. (2010). Information content of dividends: Evidence from Istanbul Stock Exchange. International Business Research, 3(3), 126-132. http://dx.doi.org/10.5539/ibr.v3n3p126

Baker, H. K., Farrelly, G. E., \& Edelman, R. B. (1985). A survey of management views on dividend policy. Financial Management, 14(3), 78-84. http://dx.doi.org/10.2307/3665062

Baker, H. K., \& Powell, G. E. (1999). How corporate managers view dividend policy? Quarterly Journal of Business and Economics, 38(2), 17-35.

Baker, M., \& Wurgler, J. (2004). A catering theory of dividends. Journal of Finance, 59(3), 1125-1165. http://dx.doi.org/10.1111/j.1540-6261.2004.00658.x

Brav, A., Graham, J. R., Harvey, C. R., \& Michaely, R. (2005). Payout policy in the 21st century. Journal of Financial Economics, 77, 483-527. http://dx.doi.org/10.1016/j.jfineco.2004.07.004

Damodaran, A. (2002). Investment valuation (2nd ed.). New York: John Wiley \& Sons.

DeAngelo, H., DeAngelo, L., \& Skinner, D. J. (2004). Are dividends disappearing? Dividend concentration and the consolidation of earnings. Journal of Financial Economics, 72(3), 425-456. http://dx.doi.org/10.1016/S0304-405X(03)00186-7

DeAngelo H., DeAngelo, L., \& Stulz, R. M. (2006). Dividend policy and the earned / contributed capital mix: A test of the life-cycle theory. Journal of Financial Economics, 81(2), 227-254. http://dx.doi.org/10.1016/j.jfineco.2005.07.005

Denis, D. J., \& Osobov, I. (2008). Why do firms pay dividends? International evidence on the determinants of $\begin{array}{lllll}\text { dividend policy. Journal of Financial Economics, } & 89(1), & \text { 62-82. }\end{array}$ http://dx.doi.org/10.1016/j.jfineco.2007.06.006

Fama, E. F., \& Babiak, H. (1968). Dividend policy: An empirical analysis. Journal of the American Statistical Association, 63, 1132-1161. http://dx.doi.org/10.1080/01621459.1968.10480917

Fama, E. F., \& French, K. R. (2001). Disappearing dividends: Changing firm characteristics or lower propensity to pay? Journal of Financial Economics, 60, 3-43. http://dx.doi.org/10.1016/S0304-405X(01)00038-1

Gaver J., \& Gaver, K. M. (1993). Additional evidence on the association between the investment opportunity set and corporate financing, dividend, and compensation policies. Journal of Accounting and Economics, 16(1-3), 125-160. http://dx.doi.org/10.1016/0165-4101(93)90007-3

Grinstein, Y., \& Michaely, R. (2005). Institutional holdings and payout policy. Journal of Finance, 60(3), 
1389-1426. http://dx.doi.org/10.1111/j.1540-6261.2005.00765.x

Grullon, G., Michaely, R., \& Swaminathan, B. (2002). Are dividend changes a sign of firm maturity? Journal of Business, 75(3), 387-424. http://dx.doi.org/10.1086/339889

Jensen, G. R., Donald, P. S., \& Zorn, T. S. (1992). Simultaneous determination of insider ownership, debt, and dividend policies. Journal of Financial and Quantitative Analysis, 27(2), 247-263. http://dx.doi.org/10.2307/2331370

Jensen, M. C., \& Meckling, W. H. (1976). Theory of the firm: Managerial behavior, agency costs and ownership structure. Journal of Financial Economics, 3, 305-360. http://dx.doi.org/10.1016/0304-405X(76)90026-X

Jensen, M. C. (1986). Agency costs of free cash flow, corporate finance, and takeovers. American Economic Review, 76, 323-329.

Kallapur, S., \& Trombley, M. A. (1999). The association between investment opportunity set proxies and realized growth. Journal of Business Finance \& Accounting, 26, 505-519. http://dx.doi.org/10.1111/1468-5957.00265

Kirkulak, B., \& Kurt, G. (2010). Are dividends disappearing or shrinking? Evidence from the Istanbul Stock Exchange. Emerging Markets Finance and Trade, 46(2), 38-52. http://dx.doi.org/10.2753/REE1540-496X460203

Kuzucu, N. (2015). A Survey of managerial perspective on corporate dividend policy: Evidence from Turkish listed firms. International Journal of Research in Business and Social Science, 4(2), 1-19. Retrieved August 22, 2015, from http://www.ssbfnet.com/ojs/index.php/ijrbs/article/view/418/410

La Porta, R., Lopez-De-Silanes, F., Shleifer, A., \& Vishny, R. (2000). Agency problems and dividend policy around the world. Journal of Finance, 55, 1-33. http://dx.doi.org/10.1111/0022-1082.00199

Lintner, J. (1956). Distribution of incomes of corporations among dividends, retained earnings and taxes. American Economic Review, 6, 97-113.

Michaely, R., Thaler, R. H., \& Womack, K. (1995). Price reactions to dividend initiations and omisions: $\begin{array}{lllll}\text { Overreaction or drift. Journal of Finance, 50, } & \text { 573-608. }\end{array}$ http://dx.doi.org/10.1111/j.1540-6261.1995.tb04796.x

Michel, A. (1979). Industry influence on dividend policy. Financial Management, 8(3), 22-26. http://dx.doi.org/10.2307/3665034

Miller, M. H., \& Modigliani, F. (1961). Dividend policy, growth, and the valuation of shares. Journal of Business, 34, 411-433. http://dx.doi.org/10.1086/294442

Miller, M. H., \& Scholes, M. S. (1978). Dividends and taxes. Journal of Financial Economics, 6, 333-364. http://dx.doi.org/10.1016/0304-405X(78)90009-0

Myers, S., \& Majluf, N. (1984). "Corporate financing and investment decisions when firms have information that investors do not have. Journal of Financial Economics, 13(2), 187-221. http://dx.doi.org/10.1016/0304-405X(84)90023-0

Pruitt, S. W., \& Gitman, L. J. (1991). The interactions between the investment, financing and dividend decisions of major US firms. Financial Review, 26(3), 409-430. http://dx.doi.org/10.1111/j.1540-6288.1991.tb00388.x

Rozeff, M. S. (1982a). Growth, beta, and agency costs as determinants of dividend payout ratios. Journal of Financial Research, 5(3), 249-259. http://dx.doi.org/10.1111/j.1475-6803.1982.tb00299.x

Rozeff, M. S. (1982b). Industry influence on dividend policy in a firm-specific model. Working paper series, 82-21. Retrieved October 1, 2014, from http://ssrn.com/abstract=903221

Shleifer, A., \& Vishny, R. (1986). Large shareholders and corporate control. Journal of Political Economy, 94(3), 461-488. http://dx.doi.org/10.1086/261385

Skinner, D. J., \& Soltes, E. F. (2011). What do dividends tell us about earnings quality? Review of Accounting Studies, 16(1), 1-28. http://dx.doi.org/10.1007/s11142-009-9113-8

Smith, C. W., \& Watts, R. L. (1992). The investment opportunity set and corporate financing, dividend, and compensation policies. Journal of Financial Economics, 32(3), 263-292. http://dx.doi.org/10.1016/0304-405X(92)90029-W

Wooldridge, J. M. (2010). Econometric Analysis of Cross Section and Panel Data (2nd ed.). Cambridge: MIT Press. 
Yilmaz, M. K. (2003). An analysis on the dividend policy of the Istanbul Stock Exchange (ISE) corporations: Cash dividend - industry behavior relation. The Istanbul Stock Exchange (ISE) Review, 7(25\&26), 17-39.

Yurtoglu, B. (2000). Ownership, control and performance of Turkish listed firms. Empirica, 27, 193-222. http://dx.doi.org/10.1023/A:1026557203261

\section{Note}

Note 1. This research paper is extracted from a part of the doctoral dissertation of the author at Marmara University. E-mail: narmankuzucu@gmail.com

\section{Copyrights}

Copyright for this article is retained by the author(s), with first publication rights granted to the journal.

This is an open-access article distributed under the terms and conditions of the Creative Commons Attribution license (http://creativecommons.org/licenses/by/3.0/). 